\title{
OCCUPATIONAL NOISE LEVEL IN MECHANIZED AND SEMIMECANIZED HARVEST OF COFFEE FRUITS
}

\author{
José Antonio Ramos da Silva ${ }^{1}$, Geraldo Gomes de Oliveira Júnior ${ }^{2}$, Carlos Emanuel de Melo Costa ${ }^{3}$, \\ Adriano Bortolotti da Silva ${ }^{4}$, Camila Pires Cremasco Gabriel ${ }^{5}$, Fernando Ferrari Putti ${ }^{6}$
}

(Received: May 09, 2018; accepted: August 13, 2018)

\begin{abstract}
Coffee cultivation has undergone significant changes, especially with regard to the mechanization process of the various existing operations that were previously carried out manually by the workers. It is observed that the intensification of mechanized activities can expose workers to noise levels capable of compromising their hearing health. In this sense, the objective in the present study was to determine the level of occupational noise in the activities of mechanized and semimechanized harvesting of coffee fruits and compare them with the limits of tolerance of the current legislation. The occupational noise level was determined considering the exposure of homogeneous groups, using an integrative meter for personal use, noise dosimeter, electromechanically calibrated and with field calibration. The results demonstrate that the noise levels found are above the limits allowed for an 8-hour working day. The highest observed level was $100.7 \mathrm{~dB}(\mathrm{~A})$ in the sweeping operation with the blower equipment and the lowest level $89.0 \mathrm{~dB}(\mathrm{~A})$ in the auxiliary activity of the selected collection equipment Vicon H3000. Harvesting activity with a portable mechanical stripper equipment showed a noise level $4.2 \%$ higher compared to harvesting with automotive harvester equipment.
\end{abstract}

Index terms: Coffee cultivation, mechanization, occupational risk.

\section{NÍVEL DE RUÍDO OCUPACIONAL NA COLHEITA MECANIZADA E SEMIMECANIZADA DOS FRUTOS DO CAFEEIRO}

RESUMO: A cafeicultura tem passado por mudanças significativas, em especial no que se refere ao processo de mecanização das diversas operações existentes que anteriormente eram realizadas manualmente pelos trabalhadores. Observa-se que a intensificação das atividades mecanizadas pode expor trabalhadores a níveis de ruído capazes de comprometer sua saúde auditiva. Nesse sentido o objetivo do presente estudo foi determinar o nível de ruído ocupacional nas atividades de colheita mecanizada e semimecanizada dos frutos do cafeeiro e compara-los com os limites de tolerância da legislação vigente. O nível de ruído ocupacional foi determinado, considerando-se a exposição de grupos homogêneos, utilizando-se medidor integrador de uso pessoal, dosímetro de ruído, calibrados eletromecanicamente e com aferição de campo. Os resultados demonstram que os níveis de ruído encontrados estão acima dos limites permitidos para uma jornada de 8 horas de trabalho. O maior nível observado foi de $100,7 \mathrm{~dB}(\mathrm{~A})$ na operação de varrição com o equipamento soprador e o menor nível $89,0 \mathrm{~dB}(\mathrm{~A})$ na atividade de auxiliar do equipamento recolhedora selecta H3000 Vicon. A atividade de colheita com o equipamento derriçadeira portátil apresentou nível de ruído 4,07\% mais elevado em relação a colheita com o equipamento colhedora automotriz.

Termos para indexação: Cafeicultura, mecanização, risco ocupacional.

\section{INTRODUCTION}

Coffee production is an important activity in Brazilian agribusiness (APARECIDO et al., 2017), responsible for a large financial movement in the country, as well as being a financial base for several municipalities and regions (FERREIRA JÚNIOR et al., 2015).

It has been verified that the activities of the coffee crop have undergone significant changes over time, especially with regard to the mechanization process of the several existing operations that were previously performed manually by the workers (CUNHA et al., 2016).
The harvesting process is one of the main coffee operations that influence the production activity, and due to the need for changes, these activities are carried out through mechanized systems, being able to be harvesters and / or mechanical stripper (SANTINATO et al., 2015; SILVA et al. 2013).

Studies have shown that the harvest yield of semi-mechanized fruits is eight times higher than the manual harvest (MATIELLO et al., 2013 ) and that manual harvesting is $50 \%$ to $60 \%$ more expensive than mechanized harvesting (SANTINATO et al., 2014).

\footnotetext{
1,2Intituto Federal de Educação, Ciência e Tecnologia do Sul de Minas - Campus Muzambinho - Estrada de Muzambinho, Km 35, Cx. P. 02 - 37.890-000 - Muzambinho-MG - jaramos@gmail.com, geraldo.junior@muz.ifsuldeminas.edu.br ${ }_{3,4}^{3,4}$ niversidade José do Rosário Vellano/UNIFENAS - Rodovia MG 179 Km 0 - Cx. P. 23 - 37.130-000 - Alfenas - MG adriano.silva@unifenas.br

5,6 Universidade Estadual Paulista/UNESP - Campus Tupã - Av. Domingos da Costa Lopes, 780 - 17.602-496 - Tupã - SP camila@tupa.unesp.br, fernandoputti@tupa.unesp.br
} 
However, even contributing to the optimization of agricultural operations, the intensification of the use of mechanized equipment in the coffee harvesting process can expose workers to high levels of noise that, depending on the intensity and time of exposure, can compromise their occupational health (LIMA JÚNIOR et al., 2014; VALLONE et al., 2016).

In this way, exposure to noise over a long period can lead to hearing loss, psychological damage, sleep disturbances, cardiovascular alterations, immune system dysfunction, fatigue, irritability, also increase the risk of work-related accidents and decrease the performance of workers (SILVA et al., 2014).

Noise is a type of sound or mixture of these that has the capacity to cause harm to the health of the people who perceive it, characterized by being a set of unpleasant sounds in the ear of individuals (COSTA et al., 2015).

It is worth noting that hearing loss, in addition to the physiological and mental damages caused to the worker, may also progress to more severe stages over the years (SANTOS; ALMEIDA, 2016).

Therefore, the quantitative evaluation of the physical noise risk allows verifying that the limits of tolerance are within those allowed in the current legislation, subsidizing the selection of occupational protection measures to reduce the health damages of workers who are connected to these operations (SANT'ANA; ZANNIN, 2016).

In this sense, the objective in the present study was to determine the level of occupational noise in the mechanized and semi-mechanized harvesting activities of coffee fruits and compare them with the tolerance limits of the current legislation, since the tolerance limit is $85 \mathrm{~dB}$ (A) for an 8-hour workday and $82 \mathrm{~dB}$ (A) for the action level, according to Regulatory Standard NR 15 and Occupational Hygiene Standard NHO 01.

\section{MATERIAL AND METHODS}

The present case study was carried out at São Manoel Farm, located in the municipality of Muzambinho, in the south of Minas Gerais, with a total area of 98 ha, of which 60 ha are occupied by coffee cultivation, whose average annual production is 2,400 bags per year.

Data collection was carried out during coffee harvesting activities from July to August 2017, in the so-called "Café do Curral", red catuaí 144 variety, spacing 3.5 x 0.8 m; "Café da Casa", red catuaí 144 , spacing 3.5 x $0.8 \mathrm{~m}$; "Café da Paineira", red catuaí 144, spacing 3.6 x $0.8 \mathrm{~m}$ and "Café do Coqueiro", acaiá variety, spacing $2.5 \times 1.0 \mathrm{~m}$.
The evaluation was performed by means of the quantification of the occupational noise level for the activities developed in the mechanized and semi-mechanized harvesting stage, using the automotive harvester Electron Auto TDI, MWM D229-4 model, with booth, 2012 manufacturing, 4 engine cylinders, power of $67 \mathrm{hp}$, working with a rotation of $1800 \mathrm{rpm}$; the portable mechanical stripper Shindaiwa, C230 model, with 22.5/1.4 displacement $\left(\mathrm{cc} / \mathrm{Pol}^{3}\right)$, with power/rpm of 1.2 $\mathrm{hp} / 7500 \mathrm{rpm}$; homemade blower, with SWZ blower turbine, with working rotation of 2200 rpm; the SWZ picker, B-900 model, 2016 manufacturing, work rotation of $1450 \mathrm{rpm}$ and the Vicon picker, model Selecta H3000 Bag Bag, manufacturing 2011, work rotation $2200 \mathrm{rpm}$ and an auxiliary worker positioned at the coffee exit in the Vicon picker (Figure 1).

The implements, blower and pickers SWZ and Vicon were dragged by the Yanmar tractor, 1155-4 SR model, year of manufacture 2010, power of $40.5 \mathrm{kw}(55 \mathrm{hp})$, unmanned.

The data collection was done in a way to represent the working day, respecting the meal schedule, totaling 8 hours of work a day.

The noise quantification was developed in order to characterize the exposure of workers through homogeneous groups, considering the following treatments: Harvester, Blower; SWZ picker; Vicon picker, Vicon auxiliary picker and Shindaiwa C230 picker.

For the data collection, 21 (twenty-one) dosimetry repetitions were performed for the picker, 5 (five) for the harvester, blower, pickers and Vicon auxiliary picker.

For this study, the noises were classified as continuous and for their evaluation was used personal integrator meter, noise dosimeter DOS100 model of SKILL TEC brand, which were calibrated electromechanically with certificate of the Brazilian Calibration Network (RBC) and calibration before and after the evaluation, using the CAL-4000 calibrator, INSTRUTHERM, IEC 942/CLASSE 2, with output sound pressure levels of 94 and $114 \mathrm{~dB}$.

The dosimeter was set up according to the following parameters: reference criterion of $85 \mathrm{~dB}$ (A), which corresponds to the $100 \%$ dose for an 8 hours exposure, integration threshold level of 80 $\mathrm{dB}(\mathrm{A})$, increased dose doubling of $3 \mathrm{~dB}(\mathrm{q}-3)$ and indication of occurrence levels above $115 \mathrm{~dB}$ (A) (GIAMPAOLI et al., 2001). 
a)

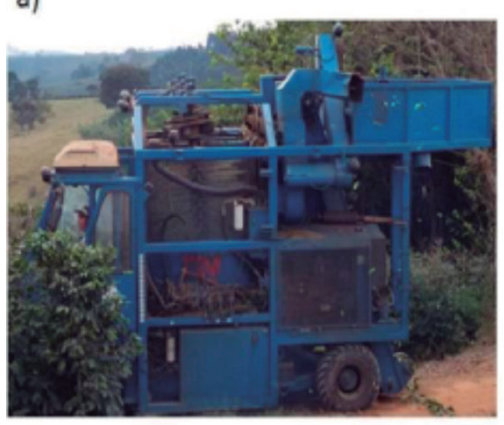

d)

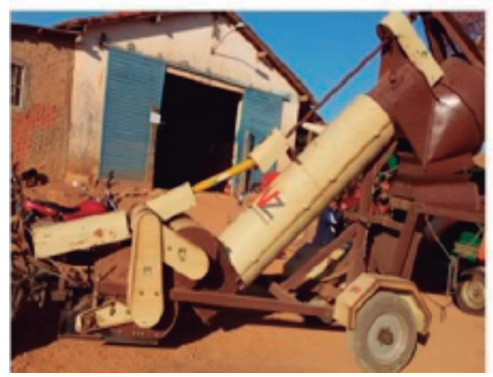

b)

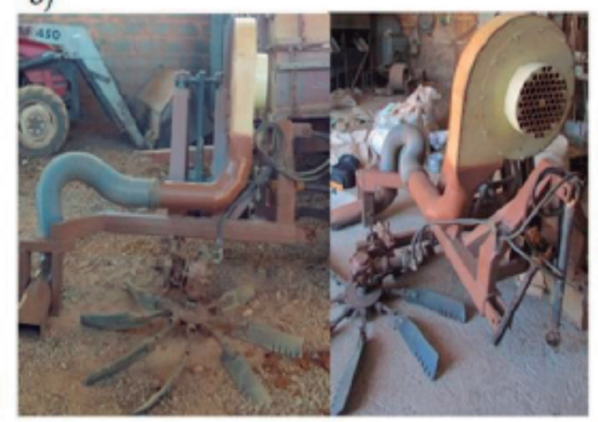

e)

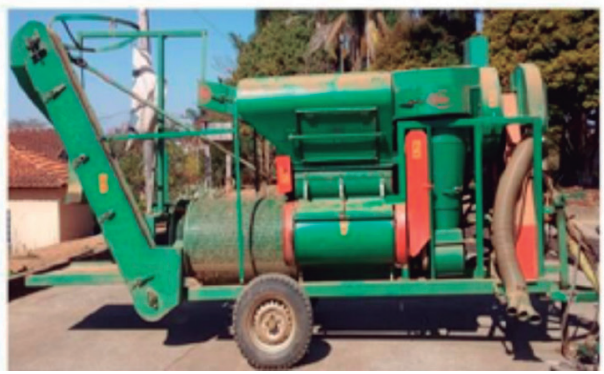

c)

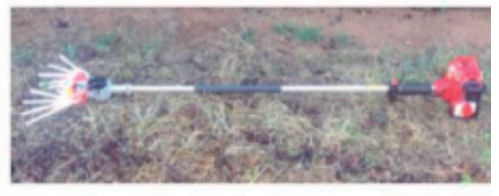

f)

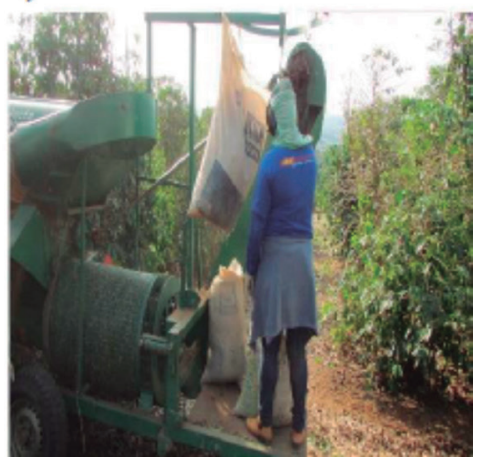

FIGURE 1 - Equipment used in mechanized and semi-mechanized harvesting coffee fruits: a) automotive harvester Electron Auto TDI, b) homemade blower, c) portable mechanical stripper, d) SWZ picker, e) Vicon picker and f) auxiliary worker position in the Vicon picker.

Throughout the data collection process, a wind shield was used in the dosimeter microphone to avoid possible air velocity interference and to protect the microphone against dust, as recommended by Giampaoli et al. (2001).

The noise dosimeter was installed with the microphone positioned in the auditory zone, near the ear of the worker. After the evaluation and data collection, the SEL- Standard Exposure Level in $\mathrm{dB}$ (A) was determined, using the following expression:

$S E L=E L+10 \log \left(\frac{T_{E}}{480}\right)[d B(A)]$

On what,

EL - is the exposure level: it is the average representative level of daily occupational exposure; and

$T_{E}$ - is the duration time, in minutes, of the daily workday.

The Exposure Level (EL) - was calculated by the following formula:

$E L=10 \log \left[\left(\frac{480}{T_{E}}\right) \times\left(\frac{D}{100}\right)\right]+85$
On what,

EL - is the level of exposure;

$\mathrm{T}_{\mathrm{E}}$ - is the duration time, in minutes, of the daily workday.

D - Daily dose of noise in percentage;

For this criterion it is considered as action level the SEL value equal to $82 \mathrm{~dB}(\mathrm{~A})$.

Note that the working day established was 8 hours daily (480 minutes) to which workers were exposed to the physical agent noise, therefore $T_{E}$ will be 480 minutes daily.

After the evaluation, the mean results obtained were compared with the tolerance limits established by the Occupational Hygiene Standard NHO 01 (GIAMPAOLI et al., 2001). From the mean data found, the maximum time of exposure to occupational noise in which the operators and auxiliary workers could be exposed without adequate ear protection was evaluated, and for the intermediate values found, the maximum allowable daily exposure was considered relative to the immediately higher level according to Occupational Hygiene Standard NHO 01 (CUNHA; TEODORO, 2006).

Data on the occupational noise levels of the mechanized and semi-mechanized harvesting 
activities of the coffee crop were then submitted to analysis of variance using the $\mathrm{F}$ test. In cases in which the $\mathrm{F}$ test value was significant, tests were performed comparing Tukey's mean, at the 5\% level of significance. For this, the computational statistical software "SISVAR" was used.

\section{RESULTS AND DISCUSSION}

In the coffee mechanized harvesting, the stripping stage is carried out with automotive equipment and the sweeping and harvesting stages are performed with sweeping implements and pickers coupled to the tractor and may or may not have the presence of helpers. The results demonstrate that the continuous / intermittent noise level at all stages of the mechanized operations of the coffee harvest exceeded the reference criterion that limits the daily exposure limits, which correspond to a dose of $100 \%$ for the exposure of 8 hours at the level of $85 \mathrm{~dB}$ (A) (Table 1).

It was observed that the lowest noise level was found in the activity performed by the equipment's auxiliary of the Vicon picker, with $89.0 \mathrm{~dB}(\mathrm{~A})$ and the highest level, in the sweeping activity, using the blower equipment, with 100.7 $\mathrm{dB}(\mathrm{A})$ (Table 1). It is worth mentioning that exposure to noise above tolerance limits can generate occupational health problems, such as hearing loss, as well as negatively influencing, reducing the efficiency of the operations (MASSA et al., 2012).

It should also be noted that the activities using the equipments: the harvester TDI MWM D229-4 and the picker Vicon Selecta H3000, as well as the activities with the picker SWZ and the operation's auxiliary of the Vicon Selecta H3000 did not present statistical differences between them (Table 1), however, all noise levels are above the tolerance limits.

It was also verified that, although the Yanmar 1155-4 SR tractor, carried out the sweeping activities with the blowing equipment and the picking activity with the selecta H3000 Vicon equipment, at the same rotation, the noise levels found presented a difference of $7.8 \mathrm{~dB}$ (A), demonstrating the influence of the coupled implement for the generation of the noise level.

For the stripping and harvesting of the coffee tree fruits, in addition to the use of automotive equipment, portable mechanical Stripper have been used in semi-mechanized operations, replacing the activity that was previously performed manually.
In the present study, the equipment, mechanical stripper and automotive harvester, presented noise levels above $85 \mathrm{~dB}$ (A) allowed for an 8-hour work day (Table 2).

The average level of occupational noise obtained in the harvesting activity with the evaluated portable mechanical stripper equipment, whose value is $97.8 \mathrm{~dB}(\mathrm{~A})$, is below the values found by Cunha and Teodoro (2006) $104,6,100,7$ e 102,2 $\mathrm{dB}(\mathrm{A})$ respectively, when evaluating different types of mechanical stripper. Also, according to the same authors, when the mechanical stripper worked at idle, the average level of occupational noise reached high values approaching the acceptable maximum limit. Possibly the difference in noise levels found between the present study 2017 and the values pointed out by Cunha and Teodoro (2006) stems from the evolution in the equipment of the breakers over time, considering that the work of Cunha and Teodoro was carried out 11 years ago.

It is worth noting that the harvesting activity with the mechanical stripper equipment presented a higher level of occupational noise compared to that found in the harvesting activity using automotive harvester equipment, that is, the automotive harvester emitted $4.2 \%$ less occupational noise when compared to the mechanical stripper. According to Sales et al. (2015) the activity with the operation of the collapsible equipment can present a high potential of health risk of the workers in function of the level of noise to which they are exposed during the activities of semi-mechanized harvesting.

Therefore, comparing the exposure time and the occupational noise level found, it is verified that the workers involved in all activities of mechanized and semi-mechanized coffee harvesting cannot carry out their activities without the use of adequate ear protection, as seen that according to the Regulatory Standad NR 15 and Occupational Hygiene Standard NHO 01, the exposure of workers to occupational noise levels exceeding $85 \mathrm{~dB}(\mathrm{~A})$ exceeds the tolerance limit for an 8-hour working day (BRAISL, 1978; GIAMPAOLI et al., 2001).

Also, according to Regulatory Standard NR 15, the exposure of workers to occupational noise levels of more than $85 \mathrm{~dB}(\mathrm{~A})$ for an 8-hour workday, without due preventive control, requires the payment of an additional health insurance of 20\% (BRASIL, 1978). 
From the analysis of Figure 2, it is possible to observe the behavior of the data in the mechanized and semi-mechanized coffee harvest stages, since these present good behavior, that is, they do not present great variation, being able to say that the data of the noise levels generated by the mechanized and semi-mechanized harvesting operations of coffee trees did not suffer significant variations (Figure 2).

Table 3 shows the maximum allowable daily times for noise exposure by workers, considering whether the levels found in each work situation evaluated, as recommended by Occupational Hygiene Standard NHO 01 (GIAMPAOLI et al., 2001).

It is also worth noting that the exposure limit, also known as the tolerance limit, does not constitute the protection of all workers involved in the activity, since Occupational Hygiene Standard NHO 01 defines as the exposure limit the parameter that represents conditions on which it is believed that most workers may be exposed repeatedly without adverse effects on their ability to hear and understand normal conversation (GIAMPAOLI et al., 2001).

TABLE 1 - Average noise level in mechanized coffee harvesting.

\begin{tabular}{ccccccc}
\hline Tractor / Harvester & RPM & $\begin{array}{c}\text { Implement } \\
\text { activity }\end{array}$ & Model & Noise dB(A)* & CV (\%) \\
\hline Yanmar 1155-4 SR & 2200 & Blower & Home made & $100.7 \pm 0.51$ & a & \\
Automotive harvester & 1800 & - & TDI MWM D229-4 & $93.8 \pm 2.49$ & b & \\
Yanmar 1155-4 SR & 2200 & Picker & Vicon Selecta H3000 & $92.9 \pm 0.64$ & b & 1,3 \\
Yanmar 1155-4 SR & 1450 & Picker & SWZ & $89.1 \pm 0.20$ & c &
\end{tabular}

Means followed by the same letter in the column do not differ by Tukey's test. * They are not significant (P>0.05) and are significant $(\mathrm{P} \leq 0.05) .{ }^{1} \mathrm{CV}$ - Coefficient of variation.

TABLE 2 - Comparison of mean noise level in mechanized and semi-mechanized harvesting of coffee.

\begin{tabular}{ccllc}
\hline Harvest type & Equipment & \multicolumn{2}{c}{ Noise dB(A)* } & CV (\%) $^{\mathbf{1}}$ \\
\hline Semi-mechanized & Mechanical stripper Shindaiwa & $97.8 \pm 1.78$ & a & 2,0 \\
Mechanized & TDI Automotive Harvester & $93.8 \pm 2.49$ & b & \\
\hline
\end{tabular}

Means followed by the same letter in the column do not differ by Tukey's test. ${ }^{*}$ They are not significant $(\mathrm{P}>0.05)$ and are significant $(\mathrm{P} \leq 0.05) .{ }^{1} \mathrm{CV}$ - Coefficient of variation.

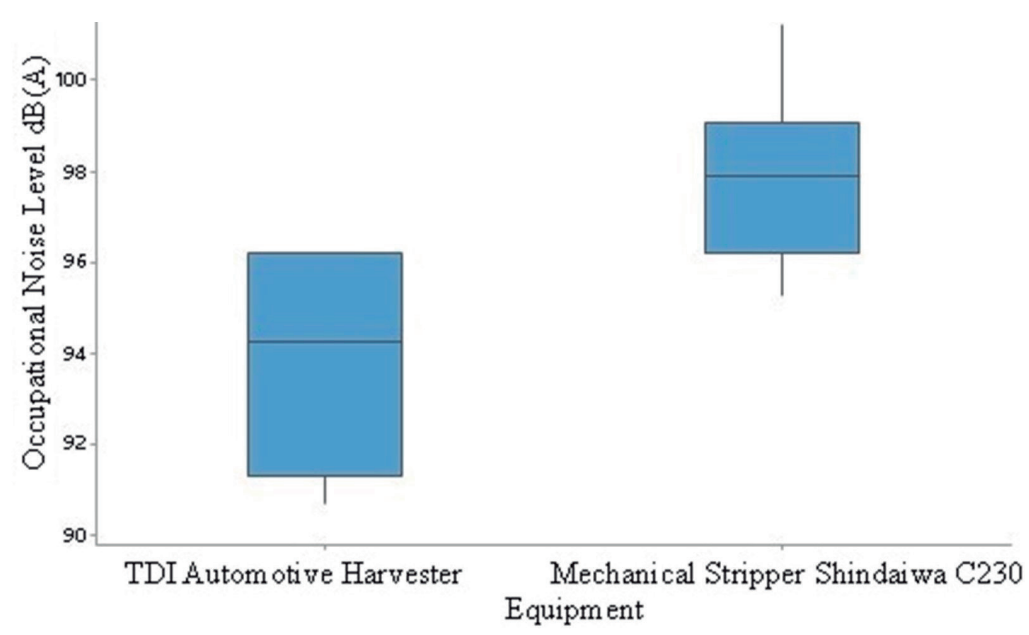

FIGURE 2 - Box-plot of noise dB (A) generated by the TDI automotive harvester and Mechanical Stripper Shindaiwa C230. 
TABLE 3 - Maximum permissible daily exposure time in the use of mechanized and semi-mechanized equipment in the coffee harvesting activity according to Occupational Hygiene Standard NHO 01.

\begin{tabular}{lccc}
\hline \multicolumn{1}{c}{ Equipment / Activity } & Noise dB(A) & Exposure time* $^{*}$ & CV (\%) $^{\mathbf{1}}$ \\
\hline Blower & $100.7 \pm 0.51$ & $11.90 \mathrm{~min}$ \\
Mechanical Stripper Shindaiwa & $97.8 \pm 1.78$ & $23.81 \mathrm{~min}$ \\
Automotive harvester & $93.8 \pm 2.49$ & $60.00 \mathrm{~min}$ & 1,6 \\
Picker & $92.9 \pm 0.64$ & $75.59 \mathrm{~min}$ & $190.48 \mathrm{~min}$ \\
Picker & $89.1 \pm 0.20$ & $190.48 \mathrm{~min}$ & \\
Auxilary & $89.0 \pm 0.10$ &
\end{tabular}

\section{CONCLUSIONS}

Under the conditions in which the study was conducted, it was concluded that the noise levels in mechanized and semi-mechanized harvesting activities are above the limits allowed for an 8-hour workday, and individual protection devices should be used to attenuate to the tolerance limit in order to improve working conditions for the workers.

The highest noise level was found in the sweeping operation with the use of the blower equipment with $100.7 \mathrm{~dB}(\mathrm{~A})$ and the lowest value in the sweeping activity with the auxiliary of the picker equipment selecta H3000 Vicon with 89.0 $\mathrm{dB}(\mathrm{A})$.

Harvesting activity with portable mechanical stripper equipment showed a $4.2 \%$ higher noise level compared to harvesting with automotive harvester equipment.

\section{ACKNOWLEDGEMENTS}

We would like to thank the Federal Institute of Education, Science and Technology of the South of Minas (IFSULDEMINAS) - Campus Muzambinho for the financial and technological support and to the owners and employees of the São Manoel farm that collaborated with the study data collection.

\section{REFERÊNCIAS}

APARECIDO, L. E. de O. et al. Agrometeorological Models for Forecasting Coffee Yield. Agronomy Journal, Madison, v. 109, n. 1, p. 249-258, Jan./Feb. 2017.

BRASIL. Ministério do Trabalho e Emprego. Portaria 3.214, de jul. 1978. Normas regulamentadoras de segurança e saúde no trabalho - NR-15: atividade e operações insalubres. Brasília, 1978. Available in: $<$ http//:trabalho.gov.br/seguranca-e-saude-no-trabalho/ legislacao/item/3679-portaria-3-214-1978>. Access on: 01 Aug 2018.
COSTA. J. B. da. et al. Caracterização do perfil audiológico em trabalhadores expostos a ruídos ocupacionais. Estudos, Goiânia, v. 42, n. 3, p. 273-287, May. 2015.

CUNHA, J. P. A. R.; TEODORO, R. E. F. Avaliação do nível de potência sonora em derriçadeiras e pulverizadores motorizados portáteis utilizados em lavouras de café. Bioscience Journal, Uberlândia, v. 22, n. 3, p. 71-77, Sept. 2006.

CUNHA, J. P. B.; SILVA, F. M.; DIAS, R. E. B. A. Eficiência de campo em diferentes operações mecanizadas na cafeicultura. Coffee Science, Lavras, v. 11, n. 1, p. 76-86, Jan./Mar. 2016.

GIAMPAOLI, E. et al. Norma de Higiene Ocupacional. Procedimento Técnico. Avaliação da Exposição Ocupacional ao Ruído. NHO 01. São Paulo: Fundacentro, 2001. 37 p.

JÚNIOR, L. de. G. F. et al. S. Recomendação para colheita mecânica do café baseado no comportamento de vibração das hastes derriçadoras. Ciência Rural, Santa Maria, v. 46, n. 2, p. 273-278, Feb. 2016.

JÚNIOR. P. da. S. L. et al. Nível de ruído emitido por conjunto trator recolhedora de café. Revista Agrarian, Dourados, v. 7, n. 25, p. 426-433, July./ Sept. 2014.

MASSA, C. G. P. et al. P300 in workers exposed to occupational noise. Brazilian Journal of Otorhinolaryngology, São Paulo, v. 78, n. 6, p. 107112, Nov./Dec. 2012.

MATIELlO, J. B.; ALMEIDA, S. R.; GARCIA, A. W. R. Mecanização em cafezais. Varginha: Fundação PROCAFÉ, 2013. 56P. 
SALES, R. S.; SILVA, F. M.; SILVA, F. C. Doses de ruídos a qual estão submetidos operadores de derriçadeiras portáteis de café. Coffee Science, Lavras, v. 10, n. 2, p. 169-175, Apr./June. 2015.

SANT'ANA, D. Q.; ZANNIN, P. H. Ruído ocupacional em estações de ônibus - estudo de caso em estações tubo - Curitiba - Paraná - Brasil. Revista RA'EGA - O Espaço geográfico em Análise, Curitiba, v. 37, p. 110-130, May./Aug. 2016.

SANTINATO, F. et al. Análise quali-quantitativa da operação de colheita mecanizada de café em duas safras. Coffee Science, Lavras, v. 9, n. 4, p. 495-505, Oct./Dec. 2014.

SANTINATO, F. et al. Colheita mecanizada do café em lavouras de primeira safra. Revista Brasileira de Engenharia Agrícola e Ambiental, Campina Grande, v. 19, n. 12, p. 1215-1219, Dec. 2015.
SANTOS, M.; ALMEIDA, A. Ruído e saúde ocupacional: consequências para além da hipoacusia. Revista Portuguesa de Saúde Ocupacional on line, v. 1, p. 1-3, 2016.

SILVA, F. C. da. et al. Desempenho operacional da colheita mecanizada e seletiva do café em função da força de desprendimento dos frutos. Coffee Science, Lavras, v. 8, n. 1, p. 53-60, Jan./Mar. 2013.

SILVA, J. L. L. da. et al. O ruído causando danos e estresse: possibilidade de atuação para a enfermagem do trabalho. Avances en Enferméria, Bogotá, v. 32, n. 1, p. 124-138, Jan./June, 2014.

VALLONE, M. et al. Risk exposure to vibration and noise in the use of agricultural track-laying tractors. Annals of Agricultual and Environmental Medicine. Lublin, v. 23, n. 4, p. 591-597, Oct./Dec. 2016. 